\title{
African Prehistory
}

\section{Notes and News}

DR. L. S. B. LEAKEY, in agreement with the Government of Kenya, has arranged for a PanAfrican Congress on prehistory to be held at Nairobi in January this year. An effort will be made to secure from the seventy members a desirable consensus on the terminology to be used in describing the pluvial periods and post-pluvial phases of the Pleistocene and African stone-age cultures, and also a definition of the terms 'Pliocene' and 'Pleistocene'. There will be discussions on the means of obtaining the maximum co-operation in respect of research programmes and on various other subjects. Papers will be read on the discoveries which have been made since the outbreak of war. Members of the Congress will have opportunities of visiting important archaeological sites and will no doubt be particularly interested in Olorgesailie, 42 miles from Nairobi, which Dr. Leakey described in The Times of 4 October. 'Here', he wrote, ' my wife walked suddenly on to an area so thickly strewn with Stone Age hand-axes and cleavers that one could scarcely walk over it without treading on them.' It was subsequently proved that there is a series of camp sites of Acheulean man 'such as had never before been found anywhere'. So far no trace has been found of the actual men who made these tools; but only preliminary work has yet been done and skeletal remains may later be unearthed. The Olorgesailie site has proved to be of such interest and importance that the Kenya Government has co-operated in protecting it and turning it into a 'museum on the spot'.

\section{The French Ten-year Plans}

Br the law of 30 April 1946 the French Overseas Minister was charged to prepare plans for the economic and social development of the territories which used to be called 'colonies'. A Commission with seven sub-committees has been engaged in drawing up the plans, following the principles laid down by $M$. Saller, the Director. It is necessary, he says, to transform almost completely the conditions of production. In territories where the climate is inimical to physical effort and where the density of population is small, modern scientific methods which allow the machine to take the place of man must be imposed. This will result in a profound change in the nature of productive enterprises, for utilization of mechanical means is not economic except for enterprises of some magnitude. Federation, standardization of material, intensive methods will all be necessary. Territories must be industrialized so as no longer to be dependent exclusively on importation. Public works to be erected during the next ten years must be related to productive plans and include hydro-electric plants, railways, roads, maritime and river ports. To carry out the schemes it is indispensable to create organisms in the form of State societies to operate only during the execution of the plans, and to organize permanent bodies such as co-operatives. Parallel with this economic. development there is to be a vast programme of social welfare. The necessary funds will be derived from F.I.D.E.S. (Le Fonds d'Investissements pour le Développement économique et social des Territoires d'Outre-Mer) which is to be fed by annual grants by the Metropolis and contributions by the interested territories, and from a Caisse centrale which will make loans at $\mathrm{I}$ per cent. on easy terms of repayment.

\section{News from the Cameroons}

Madame Dugast, secretary of the Société d'Études Camerounaises, wrote shortly after her return from furlough in France to inform us of the operations of her society. We quote some passages: 
'Maintenant que nous avons la joie d'être revenus au régime de travail du temps de paix, La Société (qui appartient à la grande organisation de l'Institut Français d'Afrique Noire) va continuer de susciter, d'encourager la recherche scientifique dans ce pays. Elle continuera d'éditer son Bulletin dans lequel seront imprimées des études de détails, des documents précis sur le Cameroun, qui seront de longueur et d'importance variées. Mais vous savez que plusieurs de nos chercheurs ont de très gros travaux en chantier. Ceux-ci, dépassant nos possibilités d'impression, seront édités soit dans les éditions de l'Institut Français d'Afrique Noire de Dakar, soit dans celles de l'Institut d'Ethnologie de Paris. C'est à ces deux organismes que reviendront les importantes monographies tribales et nos études linguistiques.'

The Ethnological Institute of Paris, Madame Dugast informs us, has undertaken to publish a big work by Dr. Koch on the Bamum. Father Stoll has made progress in his linguistic studies. Monsieur J. J. Mouchet, director of the North Cameroun section of IFAN, has for a long time been engaged in investigating the languages spoken by the native peoples of the Mandara mountains who have never been subjected to the Fulani.

\section{$A$ University for West Africa}

THE British Colonial Secretary, Mr. George Hall, decided to accept the recommendations of the minority of the Eliot Commission in favour of establishing a university college at Ibadan in Nigeria as the nucleus of a West African university. His reason for preferring a unitary university to two or three university colleges is that neither sufficient students of the requisite standard nor a staff of sufficiently high academic qualifications would be available for more than one really good institution, that is, one sufficiently comprehensive in its range of subjects in the faculties of arts, science, and medicine and adequately equipped for research. He is aware of the fine record of Fourah Bay in Sierra Leone and of Achimota on the Gold Coast and must know that the inhabitants of those colonies will feel bitter disappointment at his decision. He will raise no objection if Achimota wishes to introduce post-intermediate studies in atts or science alongside its teacher-training department and would agree as a temporary measure to the continuance of teaching for the B.Sc. engineeting degree. As for Sierra Leone and Gambia he envisages a new college at Freetown to embrace science as well as arts up to intermediate level. Mr. Hall hopes that the Church Missionary Society may be willing to associate itself with the new college and that this will still bear the name Fourah Bay. Now that the decision has been taken it will be well if the other three colonies rally to co-operate with Nigeria in making Ibadan a great university centre for all West Africa.

\section{Colonial Research Fellowships}

True British Colonial Secretary has instituted a number of Research Fellowships (twenty-five at present) to encourage qualified scientists to give special attention to colonial problems and to enable them to pursue research work in the British Colonial Empire. The Fellowships will normally be reserved for university graduates in the natural or social sciences under thirty-five years of age from any part of the British Commonwealth and Empire. Candidates must already have had experience of research and must give evidence that they have the ability to plan and prosecute investigations of a high quality without close and constant supervision. Fellowships will be tenable for a period of two years and carry remuneration at the rate of $£ 400$ per annum which may be increased to a maximum of $£ 750$ if the Fellow is married or in any other appropriate circumstances. Travelling expenses and the cost of any apparatus or material required for research will also be provided. Applications should be addressed to the Secretary, Colonial Research Committee, Palace Chambers, Bridge Street, London, S.W. r. 